\title{
Covid-19: perspectives and initiatives in older adults health context in Brazil
}

\author{
Covid-19: perspectivas e iniciativas \\ no contexto da saúde do idoso no Brasil
}

Maycon Sousa Pegorari (https://orcid.org/0000-0003-4015-9895) ${ }^{1}$

Daniela Gonçalves Ohara (https://orcid.org/0000-0001-7055-6168) ${ }^{1}$

Areolino Pena Matos (https://orcid.org/0000-0002-3437-5105) ${ }^{1}$

Ana Carolina Pereira Nunes Pinto (https://orcid.org/0000-0002-1505-877X) ${ }^{1}$

\footnotetext{
${ }^{1}$ Departamento de Ciências Biológicas, Curso de Graduação em Fisioterapia, Universidade Federal do Amapá. Rodovia Juscelino Kubitschek Km 02, Jardim Marco Zero. 68903419 Macapá AP Brasil. mayconpegorari@ yahoo.com.br
}

\begin{abstract}
This article provides information about COVID-19, contextualizing the national and international scenario, with an emphasis on the health of the elderly. Perspectives and initiatives for this risk group are presented, reinforcing the need to consider the aging process and not just age as the main marker in the approach of this population.
\end{abstract}

Key words COVID-19, Health of the elderly, Brazil
Resumo Este artigo fornece informações sobre a COVID-19, contextualizando o cenário nacional e internacional, com ênfase na saúde do idoso. São apresentadas perspectivas e iniciativas voltadas para esse grupo de risco, reforçando a necessidade de considerar o processo de envelhecimento e não apenas a idade como o principal marcador na abordagem dessa população.

Palavras-chave COVID-19, Saúde do idoso, Brasil 
The world is currently in the throes of a pandemic caused by severe acute respiratory coronavirus 2 (SARS-CoV-2), a novel virus that causes the coronavirus disease 2019 (COVID-19) ${ }^{1}$. Following the first reported cases in China in December 2019, COVID-19 spread rapidly, inflicting uncalculable damage on quality of life. The COVID-19 pandemic has posed far-reaching threats, especially to the economy, health, and the sustainability of healthcare systems. As of june 21st, the World Health Organization (WHO) reported over 8.5 million cases of SARS-CoV-2 infection in 213 countries and territories and more than 450 thousand deaths ${ }^{2}$. In Brazil, the first COVID-19 case seems to have occurred on February $26^{\text {th }}$, and as of June $21 \mathrm{st}$, the country had over 1 million confirmed cases and more than 50 thousand deaths ${ }^{3}$.

The risk of dying from COVID-19 increases with age. While the fatality rate is nearly $0.4 \%$ for patients under the age of $50^{4}$, it rises to $3.6 \%$ in patients aged $60-69 ; 8.0 \%$ in patients aged 70-79; and up to $14.8 \%$ and in patients over $80^{5}$. In Brazil, as of June $18^{\text {th }}, 2020$, more than $70 \%$ of deaths were amongst people above 60 years of age ${ }^{6}$. Older age is not the only risk factor associated with worse outcomes, as comorbidities such as hypertension, cardiovascular disease, diabetes, chronic respiratory disease, and chronic kidney disease also increase the risk of death ${ }^{1}$. Given that older adults experience more and more severe chronic diseases $^{7}$, older adults with multimorbidity are expected to suffer even more severe courses of COVID-19. Decline in immune function ${ }^{8}$, the proinflammatory profile, and alterations in the angiotensin-converting enzyme (ACE) 2 receptor $^{8}$ may play a role in the severity of COVID- 19 . In addition to the decline of immune function commonly observed in older adults, many older adults with comorbidities-such as hypertension and diabetes mellitus—often exhibit both a proinflammatory profile and have an upregulation of ACE2 when treated with ACE inhibitors ${ }^{10}$. It has been hypothesized that SARS-CoV-2 binding to the ACE2 receptor could be an essential mechanism for the virus to enter host cells ${ }^{10}$. This hypothesis could explain the increased virulence of COVID-19 in people with hypertension and diabetes.

Older adults may present clinically with different symptoms; they do not always have the typical symptoms such as cough, fever, fatigue, and dyspneia. Instead, older adults, especially those with frailty, may be afebrile and may not have cough, chest discomfort or sputum pro- duction. Tachypnea, delirium, tachycardia and decrease in blood pressure may also be present. To increase diagnostic accuracy and not merely rely on symptoms, clinicians should also familiarize themselves with typical imaging findings in COVID-19 patients. Both Brazilian and international studies have found that chest computed tomography (CT) is abnormal in the majority of patients with COVID-1911. Patients with SARS$\mathrm{CoV}-2$ infection usually present ground-glass opacities on CT scans, with a reticular pattern, fibrotic streaks, subpleural line, and air bronchogram $^{12,13}$. Although CTs may be similar in older and younger patients, older adults may be more likely to present extensive lung lobe involvement, and subpleural line and pleural thickening ${ }^{14}$.

Besides the above-mentioned aspects, relevant measures adopted by the WHO, but with direct impact on the elderly populations, are the severe social distancing measures-travel restrictions, cancellation of recreational activities, closures of schools, and many businesses-that are taking unprecedented socioeconomic and psychological tolls. Fear of shortages of essential provisions such as food, medications, and cleaning and hygiene supplies are a salient concern, especially among older adults ${ }^{15}$. Because older adults are at heightened risk of several diseases, including mental health problems ${ }^{16}$, isolation measures will probably disproportionately affect them. This is because, for many older adults, their only social contact is usually out of the home, such as at community centers and places of worship. For these older people, social isolation can lead to loneliness, which may then lead to depression, cognitive dysfunction, disability, cardiovascular disease, and increased mortality ${ }^{17}$.

Fortunately, several groups have anticipated the negative consequences that social isolation in older adults provoke, and have established actions. Two such organizations are the Brazilian Society of Geriatrics and Gerontology (SBGG) and the Oswaldo Cruz Foundation (Fiocruz), that have emitted recommendations related to mental health care and palliative care ${ }^{18,19}$. Specifically, the SBGG released a report advocating that chronical age should not be an isolated decision factor when deciding who to admit to intensive care units during the COVID-19 pandemic. Instead, patients should be evaluated clinically, especially in terms of their functionality. Older adults should also receive specialized attention related to advance directives upon admission to intensive care units and definition of palliative care measures ${ }^{20}$. The Brazilian National Academy 
of Palliative Care ${ }^{21}$ has also released information on palliative care in COVID-19 and is also part of the Choosing Wisely International initiative. The document translated by Choosing Wisely Brazil is a list of potential recommendations to help tackle COVID-19 in several countries. The list provides recommendations for the general public and also for health professionals, such as: "do not send frail residents of a nursing home to the hospital unless their urgent comfort and medical needs cannot be met on-site; do not intubate frail older people in the absence of a discussion with family members regarding the anticipated directives of will whenever possible" 22 .

Undeniably, palliative care must be part of the COVID-19 response, despite the fact that the WHO has not mentioned this topic in its guidelines on COVID-1923. The care perspective must also include the training of health professionals. Therefore, the National Council of Health Secretaries offers the Geriatric Health Care in COVID-19 course, with an emphasis on assessing older adults, triage and risk classification in health care networks, and palliative care ${ }^{24}$. An especially worrying situation is unfolding in long-term care institutes (LTCs), as a significant proportion of older adults reside in these living facilities. However, many of these LTCs are not adequately prepared to face the COVID-19 pandemic $^{25}$. Brazil's National Secretariat for the Promotion of Elderly Rights currently surveys these institutions to measure needs ${ }^{26}$. The Ministry of Health is also surveying the situation in LTCs and has released a technical guide for COVID-19 prevention and control in these institutes ${ }^{27}$. The SBGG and ILPI.me initiative are also reinforcing other guidelines ${ }^{26}$. The ILPI.me initiative is a website created by a Task Force that assembles renowned brazilian authorities in the Geriatrics and Gerontology field and other professionals with extensive experience in the management of ILPIs. The National Front for strengthening ILPIs has also released two other official documents ${ }^{28,29}$ aiming at providing subsidies for decision-making processes and for the allocation of resources by the responsible spheres in the emergency response to the COVID-19 pandemic. At the international level, other entities such as the $\mathrm{WHO}^{30}$, the American Geriatrics Society (AGS) ${ }^{31}$, British Geriatrics Society (BGS) ${ }^{32}$ and the Internacional Association for Gerontology \& Geriatrics (IAGG) ${ }^{33}$ also provide recommendations for COVID-19 control in LTCs.

Even if older adults are able to remain in their homes and practice social distancing to prevent infection, they still may suffer physically, psychologically, or emotionally. The most severe cases can involve elder abuse/neglect or even violence ${ }^{34}$. Caregivers may see an increase in stress when isolating for longer periods of time together with the person receiving their care and are deserving of interventions to conserve complete well-being. The suspension of most non-emergency consultations-whether through house calls, clinics, and other healthcare spaces-for possible cases of COVID-19, as well as the orientation for the older adults to remain at home, have raised concerns on the maintenance of levels of physical activity and functionality. This perspective can be worrying especially for frail older adults, including those with dementia and Parkinson's disease. Aprahamian and Cesari ${ }^{35}$ suggest that programs like Vivifrail ${ }^{36}$ can help promote physical activity.

The American College of Sports Medicine released recommendations for the quarantine period, reinforcing the importance of staying physically active ${ }^{37,38}$. It is important for the population to follow the recommendations of physical exercise professionals to adjust the practice of physical activity to daily life. It is also essential that individuals who regularly perform physical exercise maintain their practice even during times of lockdowns or social distancing. Sedentary behavior should be avoided as much as possible while staying home ${ }^{38}$. The Brazilian Association of Physical Therapy in Gerontology (ABRAFIGE) suggests adopting strategies to maintain physical-functional stimuli, and providing guidelines with booklets for families and caregivers, prescription of home exercises, and suggestions for routines ${ }^{39}$. Other recommendations include those from the International Association of Physical Therapists working with Older People (IPTOP) ${ }^{40}$, which compiled a resource to promote physical activity and exercise with older adults during COVID-19 shelter-in-place recommendations, and the initiatives by the World Federation of Occupational Therapists ${ }^{41}$.

Aprahamian and Cesari ${ }^{35}$ lay out a series of recommendations for geriatric specialists that can also be useful for other specialists and serve as a framework to guide Brazilian healthcare improvement effots. We believe they are valuable and should be enlisted here in full: 1. Bringing together interdisciplinary hospital teams from a geriatric perspective; 2. Screening for frailty, a principle also recommended by Morley and Vellas ${ }^{8}$ and by the National Institute for Health and Care Excellence (NICE) ${ }^{42}$ for critical care in adults; 3. Prevention of iatrogenic conditions; 4 . 
Monitoring of cognitive function and delirium; 5. Testing for SARS-CoV-2 infection and implement social countermeasures; 6.Monitoring of LTCs; and 7. Promoting physical activity.

Considering the Brazilian scenario and its specificities, projections of COVID-19 incidence in the upcoming weeks foreshadow severe adverse outcomes for older adults, especially for those with frailty and comorbidities ${ }^{8}$. Brazil's approach for supporting this population through the pandemic must not only consider age as the primary risk factor but rather address it with a holistic view of the complex aging process ${ }^{35}$. Actions to support older adults from this viewpoint must be comprehensive and integrated into the health care networks in the Brazilian health system.

\section{Collaborations}

MS Pegorari, DG Ohara, AP Matos e ACPN Pinto contributed to the study conception and design, and article writing and editing. All authors read and approved the final version of the article to be published. 


\section{References}

1. Shahid Z, Kalayanamitra R, McClafferty B, Kepko D, Ramgobin D, Patel R, Aggarwal CS, Vunnam RR, Sahu N, Bhatt D, Jones K, Golamari R, Jain R. COVID-19 And Older Adults: What We Know. J Am Geriatr Soc 2020; 68(5):926-929.

2. World Health Organization (WHO). Coronavirus disease (COVID-19). Situation Report - 153. 2020. [cited 2020 Jun 21]. Available from: https://www. who.int/docs/default-source/coronaviruse/situation -reports/20200621-covid-19-sitrep-153.pdf?sfvrsn=c896464d_2

3. Brasil. Ministério da Saúde (MS). Covid19. Painel Coronavirus. 2020. [cited 2020 Jun 21]. Available from: https://covid.saude.gov.br/

4. Chinese Center for Disease Control and Prevention. The epidemiological characteristics of an outbreak of 2019 novel coronavirus diseases (COVID-19) in China. Zhonghua Liu Xing Bing Xue Za Zhi 2020; 41(2):145-151.

5. Wu Z, McGoogan JM. Characteristics of and Important Lessons From the Coronavirus Disease 2019 (COVID-19) Outbreak in China: Summary of a Report of 72314 Cases From the Chinese Center for Disease Control and Prevention. JAMA 2020; 323(13):1239-1242.

6. Brasil. Ministerio da Saúde (MS). Situacao Epidemiologica da COVID-19. Doenca pelo coronavirus 2019. Boletim Epidemiologico 18. 2020. [cited 2020 Jun 21]. Available from: https://saude.gov.br/images/pdf/2020/June/18/Boletim-epidemiologico-COVID-2.pdf

7. Bandaranayake T, Shaw AC. Host Resistance and Immune Aging. Clin Geriatr Med 2016; 32(3):415432.

8. Morley JE, Velas B. COVID-19 and Older Adult. J Nutr Health Aging 2020; 24(1):1-2.

9. Lakatta EG. The reality of getting old. Nat Rev Cardiol 2018; 15(9):499-500.

10. AlGhatrif M, Cingolani O, Lakatta EG. The Dilemma of Coronavirus Disease 2019, Aging, and Cardiovascular Disease: Insights From Cardiovascular Aging Science. JAMA Cardiology 2020. doi: 10.1001/jamacardio.2020.1329.

11. Sun P, Qie S, Liu Z, Ren J, Li K, Xi J. Clinical characteristics of hospitalized patients with SARS-CoV-2 infection: A single arm meta-analysis. J Med Virol 2020; 92(6):612-617.

12. Chate R, Fonseca E, Passos R, Teles G, Shoji H, Szarf G. Presentation of pulmonary infection on $\mathrm{CT}$ in COVID-19: initial experience in Brazil. J Bras Pneumol 2020; 46(2):e20200120.

13. Wang YXJ, Liu W-H, Yang M, Chen W. The role of CT for Covid-19 patient's management remains poorly defined. Ann Transl Med 2020; 8(4):145.

14. Zhu T, Wang Y, Zhou S, Zhang N, Xia L. A Comparative Study of Chest Computed Tomography Features in Young and Older Adults With Corona Virus Disease (COVID-19). J Thorac Imaging 2020; 35(4):W97-W101.

15. Lloyd-Sherlock P, Ebrahim S, Geffen L, McKee M. Bearing the brunt of covid-19: older people in low and middle income countries. BMJ 2020; 368:m1052.
16. Gerst-Emerson K, Jayawardhana J. Loneliness as a public health issue: the impact of loneliness on health care utilization among older adults. Am J Public Health 2015; 105(5):1013-1019.

17. Berg-Weger M, Morley J. Loneliness in Old Age: An Unaddressed Health Problem. J Nutr Health Aging 2020; 24(3):243-245.

18. Sociedade Brasileira de Geriatria e Gerontologia. COVID 19. 2020. [cited 2020 Jun 21]. Available from: https://sbgg.org.br/category/covid-19/

19. Fundação Oswaldo Cruz. Covid-19 e saúde mental: cartilhas abordam cuidados paliativos e atendimento online. Brasília: Fiocruz; 2020. [cited 2020 Jun 21]. Available from: https://www.fiocruzbrasilia.fiocruz. br/covid-19-e-saude-mental-cartilhas-abordam-cuidados-paliativos-e-atendimento-online/

20. Sociedade Brasileira de Geriatria e Gerontologia. Critérios de Internação em Unidade de Terapia Intensiva para Idosos. 2020. [cited 2020 Jun 21]. Available from: https://sbgg.org.br/criterios-de-internacao-em-unidade-de-terapia-intensiva-para-idosos/

21. Academia Nacional de Cuidados Paliativos. COVID-19. 2020. [cited 2020 Jun 21]. Available from: https://paliativo.org.br/ancp/covid19/

22. Academia Nacional de Cuidados Paliativos. Choosing Wisely International inclui ANCP em material sobre COVID-19. 2020. [cited 2020 Jun 21]. Available from: https://paliativo.org.br/cwi-ancp-material-covid-19/

23. The Lancet. Palliative care and the COVID-19 pandemic. Lancet 2020; 395(10231):1168.

24. Academia Nacional de Cuidados Paliativos. Capacitação: Atenção à Saúde do Idoso na Covid19. 2020. [cited 2020 Jun 21]. Available from: http://www.conass.org br/atencao-a-saude-do-idoso-na-covid19

25. Watanabe H, Domingues M, Duarte Y. COVID-19 e as Instituicoes de longa permanencia para idosos: Cuidado ou morte anunciada? Geriatr Gerontol Aging 2020. doi: 10.5327/Z2447-2123202020142LTTR.

26. ILPI.me. Coronavirus. 2020. [cited 2020 Jun 21]. Available from: https://ILPI.me

27. Brasil. Ministério da Saúde (MS). Secretaria de Atenção Primária à Saúde. Departamento de Ações Programáticas Estratégicas. Coordenação-Geral de Ciclos da Vida. Coordenação de Saúde da Pessoa Idosa. Nota Técnica No 7/2020-COSAPI/CGCIVI/DAPES/SAPS/ MS. Brasília: MS; 2020.

28. Frente Nacional de Fortalecimento as Instituicoes de Longa Permanencia para idosos. Instituições de Longa Permanência para Idosos e o enfrentamento da pandemia de COVID-19: subsídios para a Comissão de Defesa dos Direitos do Idoso da Câmara Federal - Relatório técnico 2020. [cited 2020 Jun 21]. Available from: https://sbgg.org.br/wp-content/uploads/2020/06/Relato $\%$ CC\%81rio-final-FN_fichaC.pdf

29. Frente Nacional de Fortalecimento as Instituicoes de Longa Permanencia para idosos. Boas práticas para as Instituições de Longa Permanência para Idosos no enfrentamento da pandemia de COVID-19: estratégias e protocolos 2020. [cited 2020 Jun 21]. Available from: https://sbgg.org.br/wp-content/uploads/2020/06/Relato\%CC\%81rio-final-FN_fichaC.pdf 
30. World Health Organization (WHO). Infection prevention and control guidance for long-term care facilities in the context of COVID-19: interim guidance, 21 March 2020. Geneva: WHO; 2020. [cited 2020 Jun 21]. Available from: https://apps.who.int/iris/handle/10665/331508

31. American Geriatrics Society. American Geriatrics Society Policy Brief: COVID-19 and Nursing Homes. J Am Geriatr Soc 2020; 68(5):908-911.

32. British Geriatrics Society. COVID-19: Managing the COVID-19 pandemic in care homes. 2020. [cited 2020 Jun 21]. Available from: https://www.bgs.org.uk/resources/covid-19-managing-the-covid-19-pandemic-in-care-homes

33. Internacional Association for Gerontology \& Geriatrics. Coronavirus (COVID-19) presents high risks for older people 2020. 2020. [cited 2020 Jun 21]. Available from: https://www.iagg.info/copy-of-covid-19-response

34. Han SD, Mosqueda L. Elder Abuse in the COVID-19 Era. J Am Geriatr Soc 2020; 68(7):1386-1387.

35. Aprahamian I, Cesari M. Geriatric syndromes and SARS-Cov-2: more than just being old. J Frailty Aging 2020; 9(3):127-129.

36. Izquierdo M. Multicomponent physical exercise program: Vivifrail. Nutr Hosp 2019; 36(Spec No2):50-56.

37. American College of Sports Medicine. Staying active during the coronavirus pandemic. 2020. [cited 2020 Jun 21]. Available from: https://www.exerciseismedicine. org/assets/page_documents/EIM_Rx\%20for\%20Health_\%20Staying\%20Active\%20During\%20Coronavirus\%20Pandemic.pdf

38. Ferreira M, Irigoyen M, Colombo F, Saraiva J, Angelis K. Vida Fisicamente Ativa como Medida de Enfrentamento ao COVID-19. Arquivos Brasileiros de Cardiologia 2020; 114(4):601-602.
39. Associação Brasileira de Fisioterapia em Gerontologia. Nota da Abrafige: Assistência Fisioterapêutica à Pessoa Idosa em tempos de Covid-19. 2020. [cited 2020 Jun 21]. Available from: https://www.abrafige.com.br/ nota-da-abrafige-assistencia-fisioterapeutica-a-pessoa-idosa-em-tempos-de-covid-19/

40. World Confederation for Physical Therapy. Information and resources about COVID-19. International Association of Physical Therapists working with Older People. Resources for exercise and physical activity. 2020. [cited 2020 Jun 21]. Available from: https:// www.wcpt.org/news/Novel-Coronavirus-2019-nCoV

41. World Federation of Occupational Therapists. Occupational Therapy and the COVID-19 Pandemic - information and resources. 2020. [cited 2020 Jun 21]. Available from: https://wfot.org/news/2020/occupational-therapy-response-to-the-covid-19-pandemic

42. National Institute for Health and Care Excellence. COVID-19 rapid guideline: critical care in adults. NICE guideline [NG159]. 2020. [cited 2020 Jun 21]. Available from: https://www.nice.org.uk/guidance/ng159

Article submitted 04/05/2020

Approved 23/06/2020

Final version submitted 25/06/2020 